\title{
New Trends in Higher Education: The Impact on the University Library
}

D OUBTLESS THERE ONCE WAS A TIME in which it was logical to look to a college president for prophecies, at least as far as the future of higher learning and its supporting institutions was concerned. The college or university president had time to think, a suitable vantage point from which to see the world of learning, and a well-stocked and, more important, well-perused library of relevant books and essays.

Habits linger long after the conditions that gave rise to them have disappeared. Nowadays the president's time to think is likely to consist of little more than the hours spent on airplanes (and even that will presumably be eroded once telephones are installed in jets), plus the hours provided by insomnia. His "suitable vantage point from which to see the world of learning" is all too much of the time the academic equivalent of a foxhole, and as for his well-stocked and wellperused library he hasn't time to stock it, much less peruse it. Why should anyone expect wisdom, still less perceptive prophecy, out of a person so beset? Yet you were so incautious as to invite me, and I so rash as to accept. Indeed, I could hardly do otherwise, since I firmly believe that the library is the heart of the university, that a healthy university cannot be without a healthy library-

Richard W. Lyman, President of Stanford University, presented the following paper at the Seventy-eighth meeting of the Association of Research Libraries held in Colorado Springs, Colorado, May 1415,1971 and that not enough university presidents fully and adequately recognize these facts. So here I am.

What can the leaders of research libraries expect as a result of changes in the world of higher education during this decade? Will new groups of library users emerge while others fade from view? What will be the library-related content of higher education, and will it alter in nature or total dimensions? How will society's shifting patterns of life-styles and objectives affect the research libraries? These are the kinds of casual queries put to me by your Program Committee, a group that certainly knows how to seek blood from a turnip. Fortunately, they did not ask me about the effects of technological advances, such as the microfiche revolution, upon higher education. Of the arguments over how soon and how completely these changes will in fact take place, I can only plead ignorance and quote from Richard Brinsley Sheridan's play, The Rivals:

The quarrel is a very pretty quarrel as it stands; we should only spoil it by trying to explain it.

First, then, the matter of student population. While we are going to arrive at a much-advertised plateau, or even slip into a decline, with respect to the college-age population during the early 1980 s, estimates of the U.S. Department of Education call for an increase meanwhile in the number of degree credit students at all levels from the 7 million of 1968 to 10.3 million by $1978 .^{1}$ The percentage increases at all levels and of 
both sexes are expected to be smaller than in the previous decade, but that is scant comfort when one looks at the absolute numbers. In persons filing through the library turnstiles or lining up at the checkout counter with books under their arms, the trend is still dramatically upward.

There are voices to be heard questioning such estimates, and asking whether Americans haven't been oversold on the importance of a college education, and whether we aren't even now trying to send to college many persons who would profit more from vocational training, or immediate immersion in the job market.

I doubt that these voices will prevail. We Americans already have demonstrated a capacity for stretching the concept of a college education to include practically every form of skill or knowledge known to man (and perhaps a few that might better have been left unknown). Our ingenuity in this regard seems unlikely to flag. The growth of the community colleges suggests continuing adaptability, although opinions are mixed as to the success of these ventures in meeting the actual needs of their students.

I happen to believe that some of our difficulties derive from our rather undiscriminating notions of what constitutes "higher education"; people's expectations go unfulfilled because of them, and the tendency to reduce the whole thing to a matter of preparing for participation in the economic life of the nation has made us vulnerable to charges of Philistinism-even though some of those making the charge most energetically are themselves Philistines of a rather blatant sort. But the tendency to regard "a college education" as everyone's birthright will grow inexorably, in my opinion.

In all likelihood the educational "stretch-out," whereby even the Ph.D. does not constitute the end of the line and postdoctoral work grows apace, will continue. It may be-one must devoutly hope that it will be-the case that the prospect of still more years of preparation before a person can be considered ready to operate as a fully prepared professional will exert additional pressure upon the contemporary doctorate degree, to shorten its duration and lighten its burdens. Too many doctoral dissertations are still attempts to climb Mt. Everest, when skills that could be acquired by a brisk walk in the foothills are all that the toiler will ever need later in life. Too many dissertation directors feel such a sense of personal identification, not so much with the student as with the student's finished work, that they delay unduly the completion of the doctoral exercise while seeking perfection in the doctoral product.

Yet the total impact of all these shifts inevitably is going to be greater and more diversified demands upon research libraries. You are going to have to provide a greater diversity of services, both because they become technologically possible and because your users are going to be more and more diverse-as to age and ethnic, economic and social background. I believe it is not merely a fashionable cliché to suggest that there will be marked increases in the numbers of people dropping in and out and back into institutions of higher learning. All the signs point that way. "Future shock" cannot be contained otherwise. People's skills will become obsolete and will need refurbishing or replacement. And the increases in leisure time, for practically everybody except research library directors and university presidents, will give people both the opportunity and the motive to return to the classroom. Further, the drive for women's rights will continue to exert pressure on all institutions, including those once resistant to all thought of part-time study or over-age students.

The relationships between burgeoning state and community colleges and re- 
search libraries have yet to be worked out; we all talk about interinstitutional cooperation but its growth is halting and sporadic. The pressure of an increased and diversified student population will make still more imperative the attainment of significant progress along these lines. If progress is made towards something approaching the British "Open University" the major research libraries will have to play their part, too. The combination of these pressures should (to use a hospital analogy) increase the load upon the library's outpatient clinics, as compared to its inpatient wards. The silver lining may conceivably be a greater awareness on the part of the public and the keepers of the public purse that a great research library is not just a piece of a university, but a community asset in its own right, and therefore worthy of community support.

But now I'm poaching in the game preserves of Roman Numerals II and III on your program, the Governmental and Fiscal Environments. Back to the users.

What will all these people be doing in college or the university? How will changes in what they are studying and how they study it affect the libraries? Here again, what I have to offer is largely conventional wisdom. The loosening of the bonds, once provided by curriculum requirements and by compulsory reading assignments within courses, will doubtless continue, at least for a time and in most institutions. I do detect the beginnings of some backlash already, however. At Hampshire College in Massachusetts, while conventional course requirements and majors are eschewed, there is an emphasis on the need for curricular structure and a degree of diversification from each student that seems to me significant. I doubt if most students really want to be quite as free from requirements, and therefore guidance as their rhetoric would cause one to imagine-or as the ablest and most independent-minded of them in fact are. Still, there will be many, many more flowers growing in the catalog garden; that seems assured. The magic phrase, "interdisciplinary course," has not lost any of its appeal. Indeed, linked as it now is to the belief that subjects hitherto kept apart must be joined together in order to enable us to deal with the problems of our complex world, the password, "interdisciplinary," seems destined for still greater things. To some extent this is bound to feed the publishing trade with new categories of titles, although this is perhaps less likely to affect research libraries than the paperback textbook industry. More important for our purposes, the growth of new combinations of subject matter within courses will connect with the tendency to value independent study, and the research libraries can expect a greater usage from students now veering from the Reserve Book Room to the stacks, and a greater need for cross-referencing, both in bibliographic tools and by skilled reference librarians.

Even without the thrust towards interdisciplinary work, the familiar "knowledge explosion" has been raising the costs of bibliographies, indexes and abstracts to dizzy heights, as you all know. Mr. Ellsworth has said that the University of Colorado library now spends more on these items each year than its total acquisition budget fifteen years ago. ${ }^{2}$ And with a greater number of students, possessing a greater variety of backgrounds and of preparedness to use sophisticated research tools, no doubt the costs of staffing will continue to increase, so as to make available to the student the help he needs in making effective use of these bibliographic aids.

It is a commonplace also that greatly increased burdens fall upon the library because of the need to reach beyond the confines of Europe and North America in acquiring research materials. Keeping track of publications of all kinds in 
portions of the world where neither the publishing industry nor the bibliographic skills and services are well organized becomes terribly difficult. I see little likelihood that such pressures will decrease. We may or may not find ourselves tending towards some form of "neoisolationism" following our withdrawal from Southeast Asia-as Mr. Nixon says he fears will be the case. But I doubt that such shifts in the emphasis of public concerns will do much to diminish the scholarly interest in all parts of the world that gives rise to these acquisitions burdens. Proverbially, new academic areas are hard to shut down once they have been opened up. As the late dean of Yale College, Bill Devane, once observed: "The trouble with experiments in higher education is that they never fail." We had little or no scholarly competence in the Southeast Asian area before our disastrous political and military involvement there; we have little enough even now. But what we have we'll probably try to hold, and only the sheer rigors of budgetary shortage are likely to make any of us give up.

Since such rigors are having some effect, however, it might be worthwhile to utter a warning note here. If so-called "exotic" programs are eliminated because they are very expensive, and not least so in respect to their library costs, and if the job is done on an individual basis, each institution thinking only of its own programs and assuming that no one else is contemplating cutting back in the same area of study, the results will be very bad. The same pressures will tend to produce the same results everywhere if there is no effective coordination among institutions. We all agree that there should be greater efforts toward coordination in the building of specialized research collections to avoid expensive overlapping and duplication; I'm now suggesting that there must also be coordination in the dismantling of collections. If Siwash University decides that
Balinese studies are too rich for its blood, it had better get in touch with others in the field to make sure that Balinese studies do not simultaneously disappear everywhere in the country. Cooperation in trimming programs could also dovetail with cooperation in building them; the now-to-be-unused publications that comprise Siwash's Balinese collection should go over to Alligator State, whose decision has been to keep its Balinese studies program going, but to cut out Samoan studies, which are being continued at $\mathrm{Si}$ wash. And so on.

Much is being said about the need for changes in postgraduate education. If the number of doctoral programs no longer requiring a full-dress dissertation should really increase, one assumes that there would be some lessening of the pressures upon research libraries. But here, as in other matters, it becomes very difficult to distinguish between lip service to a fashionable ideal, and genuine commitment to change. As one of our most experienced college-watchers, Professor Lewis Mayhew, puts it: "There are probably good reasons to wish for a change, but in spite of the fact that 111 institutions (in his 1968-9 survey) predict a new teaching doctorate (by 1980), visits to university campuses do not reveal widespread, active interest." ${ }^{3} \mathrm{He}$ also notes that despite conflicting opinions as to the need for Ph.D.'s in the coming decade, projects abound for new programs, and not least in those fields most closely dependent upon library resources, the humanities and social behavioral sciences. How the country will respond to the alleged oversupply of Ph.D.'s is perhaps more a function of political attitudes and the resultant availability or unavailability of money than it is of scholarly or institutional choices and ambitions. Depressingly, there are only a few signs of progress towards recognition of the fact that no society can support a full-fledged university at every crossroads, nor even a first 
rate full-fledged university in every state. State colleges still press for the right to give advanced degrees; universities-inname-only still strive to become universities-in-fact. Perhaps we shall see, during the next decade, a greater readiness to see merit in a consciously intended and cheerfully accepted diversity of postsecondary educational institutions. Certainly we must hope so, for otherwise we are likely to see more of the tragic and ironic situation in which universities such as Harvard, Stanford and Princeton reduce their graduate programs, while other institutions forge ahead to create new programs despite their lack of research facilities, such as libraries strong enough to support high quality work. As a result, the libraries at Harvard, Stanford, and Princeton will not feel any significant reduction of burdens, while new and impossible ones will be placed on the shoulders of library directors elsewhere.

Let me now turn to what one might term the personal and institutional conditions of life, as they are likely to affect research libraries. Presumably the winds of freedom will continue to blow in a bewildering number of directions. More students will elect to live like other citizens, scattered through the surrounding community, rather than in dormitories close to the library doors. More will take part-time work at all levels, while holding a job or raising a family. It is probable that research institutes and "think tanks" not closely connected with any university will proliferate. Indeed, if the campuses continue to be so frequently disrupted, a great deal of research presently being done in universities may move to less threatened quarters. That will be a tragedy, in my view, for it will leave undergraduates with fewer opportunities to learn what research really is (and unlearn some of the popular myths about it), while leaving university research libraries in a most anomalous position, bereft of many of their regular users, but called upon to work out cooperative arrangements from afar with burgeoning institutional users outside the university. Again, although the pattern of use may alter significantly, the burdens of providing service seem likely only to grow, never to decline.

Furthermore it is perhaps worth noting that there are still some fields-one thinks of law immediately-where the dominant research orientation of the postWorld War II university is only now beginning to take hold. I think you will see the best law schools moving simultaneously towards practical work experiences for their students, and the promotion of more serious advanced research for both students and faculty. Not satisfied with having changed the LL.B. to a J.D. degree, the law schools can be expected to encourage postgraduate work to a significantly greater extent-again, providing only that funding can be found. And if the current crush to gain admission to our law schools continues, and if the current preoccupation on all sides with the enormous needs of our society for trained legal minds persists, even the funding problem may be solved, or at least ameliorated-no doubt to the traumatized surprise of law deans and law librarians who have become accustomed to straitened circumstances while all around them were waxing fat on federal appropriations and foundation largesse.

Against this must be set the perceptible decline in the prestige of research among many younger scholars in the humanities. Even if the teaching doctorate does not materialize to a significant extent, it may well be that the amount and kind of research which graduate students and younger faculty are willing to undertake will change, and in ways that lighten somewhat the strains upon the libraries. This is far too imponderable to judge as yet; one can only note the prevalence of disillusionment with the research mystique, and of attacks upon what the 
critics consider too literal an attempt to apply to the humanities the styles and traditions of research originally developed by the sciences.

It would be rash to conclude, however, that a diminished respect for traditional kinds of research will make the research librarian's life any easier. For one thing there is the demand for a whole host of nontraditional materials; fewer students may wish to analyze the prosody of Ezra Pound's Cantos, using editions of his works and of works on prosody, but many more will want to listen to tapes or recordings of the cantankerous old poet himself reading from the Cantos. If, as seems likely, more people take seriously the idea of lifelong education, and if, as seems very unlikely, television finally begins to contribute to the cultural life of the country in a way more worthy of its initial promise, thus stimulating the appetites of the general public for knowledge, the libraries will find themselves beset with cries for help from many outside the universities, and will have to respond.

It may be well at this point to recognize another and downright disagreeable result that may come from changing life styles. Heaven knows that we have already seen instances of brutal disregard for the fragility of a great library, and for the rights of other users. Political protests have in several institutions included vandalism directed at the library, and especially at that precious key to its use, the catalog. At Stanford last (197071) year, several thousand catalog entry cards were removed, in many cases defaced or destroyed, as part of a campaign of harassment on behalf of a library employee who had been penalized for his part in a campus disruption. There have been cases of arson in libraries that chill any booklover's heart. And politics aside, the general incidence of theft and careless or outright destructive misuse has become serious cause for concern.

It would be bad enough if one could explain such developments by the fact that many persons are now coming into contact with great libraries for the first time, and are doing so with inadequate preparation to respect their value, or to measure the seriousness of damage done to the collections or the catalogs. Unfortunately, this is almost certainly not the cause of the trouble. Rather it is merely one more expression of that pervasive disrespect for cultural heritage and for the authority of established institutions that infects rich and poor alike, but as far as one can judge seems to take more virulent hold of the rich than of the poor. In all too many cases, the new barbarians do not even have the excuse of an inadequate upbringing.

Less dramatically, but still a problem for anyone trying to manage a library, the strong populist egalitarianism of our time, combined with a love of self-assertion, will make it ever harder to devise effective regulations, especially if the thrust of those regulations is in any way to give greater privileges to some users than to others. As the complexity of services and relationships increases, and likewise the variety of materials collected by libraries, the need to keep track of users might seem greater than ever. But the chances of successfully differentiating among users according to seriousness of need are surely in decline. How could it be otherwise, in a time when some faculty (fortunately not many, as yet) seem unwilling to assert even that they know any more than students, still less that they have any legitimate claims to special attention in the library or anywhere else?

Unhappily, the demand for equal treatment generally takes the form of equal immunity for all, rather than equal subjection to rational regulation for all.

But this paper was not intended to be a political polemic, and I would return to the more general topic with one sweepingly destructive observation. It seems to me that when all of the pre- 
dicting and the extrapolation of trends is done, we are still left with the stark recognition that a few macro-events entirely outside the world of scholarship can and probably will make mockery of all efforts to peer ahead. Professor Mayhew reminds us how suddenly the assassination of Martin Luther King altered the situation with regard to the admission of disadvantaged minority students in all the major universities of the country. ${ }^{4}$ Granted, trends were already visible, headed in the same direction; but nothing so dramatic by way of enrollment increases and program innovations would have taken place without this transforming tragedy.

Similarly, the fate of the great issues of our time, from war and peace to the possible invention of breathable air, can produce sudden wrenchings or profound alterations in the course of research libraries. Short of the coming of some new Dark Ages (and how one wishes that some people knew enough human history to recognize that as a distinct possibility!), one can be reasonably sure that the future of the libraries will be shaped by the one word, "more." More materials, more users, more services, more relationships to other agencies, more dependence on advanced technology, more need for managerial and diplomatic skills of a very high order-the list is endless. You must be brave people to occupy the positions you now hold; you are not likely to require less courage in the course of the coming decade.

\section{REFERENCES}

1. Statistics of Trends in Education, National Center for Educational Statistics, U.S. Department of Health, Education and Welfare, 1970.

2. "ACLS Newsletter," 22 (January, 1971): 10.

3. Graduate \& Professional Education, 1980: A Survey of Institutional Plans. New York: 1970, p. 29.

4. Mayhew, op. cit., "Introduction," p. ix. 